\title{
PREVALENCE OF ISOSPORA BELLI IN HIV PATIENTS WITH DIARRHOEA IN SALEM, TAMILNADU
}

\author{
Kannan Gopalan'1, Eby Chacko², Mohammed Shoubin N. P3, Monisha B. M4
}

1 Professor and HOD, Department of Dermatology, Venereology and Leprology, Vinayaka Mission's Kirupananda Variyar Medical College and Hospitals, Salem, Tamilnadu.

2Junior Resident, Department of Dermatology, Venereology and Leprology, Vinayaka Mission's Kirupananda Variyar Medical College and Hospitals, Salem, Tamilnadu.

3Junior Resident, Department of Dermatology, Venereology and Leprology, Vinayaka Mission's Kirupananda Variyar Medical College and Hospitals, Salem, Tamilnadu.

${ }_{4}^{4}$ Senior Resident, Department of Dermatology, Venereology and Leprology, Vinayaka Mission's Kirupananda Variyar Medical College and Hospitals, Salem, Tamilnadu.

\section{ABSTRACT}

\section{BACKGROUND}

Intestinal parasitic infestations are associated with acute and chronic diarrhoea in HIV patients. Almost all the HIV/AIDS patients are susceptible to parasitic infections; the risk is more among those individuals whose immunity is very low. The aim of this study was to determine the prevalence of Isospora belli in HIV patients with diarrhoea.

\section{MATERIALS AND METHODS}

A total of 250 HIV patients were included. Stool examinations as fresh wet mounts and modified acid-fast stain and CD4 cells counts were also performed.

\section{RESULTS}

GIT pathogens were found in stool of 74 (29.6\%) patients with diarrhoea. The prevalence of Isospora belli was $2.7 \%$ among HIV/AIDS patients with diarrhoea. The common coccidian parasite found was Cryptosporidium parvum with a prevalence of $63.5 \%$ and noncoccidian parasite was Entamoeba histolytica with a prevalence of $28.3 \%$. The CD4 count in patients with diarrhoea of 39 patients $(52.7 \%)$ was less than 200 cells/uL, 31 patients (41.8\%) between $200-500$ cells/uL and 4 patients $(0.05 \%)$ greater than 500 cells/uL.

\section{CONCLUSION}

Even though the incidence of Isospora belli in HIV infected diarrhoea patients is very less when compared to the other GIT pathogens, routine stool examinations to be done for Isospora belli also so that it can reduce the morbidity and mortality associated with the GIT pathogens.

\section{KEYWORDS}

Intestinal Parasite, Isospora, HIV.

HOW TO CITE THIS ARTICLE: Gopalan K, Chacko E, Shoubin MNP, et al. Prevalence of isospora belli in HIV patients with diarrhoea in Salem, Tamilnadu. J. Evolution Med. Dent. Sci. 2016;5(104):7664-7667, DOI: 10.14260/Jemds/2016/1729

\section{BACKGROUND}

Diarrhoea is one of the most common presenting complaints in HIV-infected individuals. The infectious aetiological agents include both opportunistic agents that consistently cause severe, chronic or frequent gastrointestinal disease and nonopportunistic agents that usually cause acute, treatable diarrhoeal illness.[1] Chronic diarrhoea defined as persistence of diarrhoea beyond four weeks ${ }^{[2]}$ is a common symptom in HIV-infected patients in the tropics. Due to the delayed diagnosis of HIV in these individuals, the patients usually take over-the-counter drugs or local medications for symptomatic relief and the underlying disease is left untreated. In a developing country like India, this often results in weight loss and wasting syndrome leading to profound morbidity.

Financial or Other, Competing Interest: None.

Submission 24-11-2016, Peer Review 18-12-2016,

Acceptance 24-12-2016, Published 29-12-2016.

Corresponding Author:

Dr. Kannan Gopalan,

Professor and HOD

Department of Dermatology, Venereology \& Leprology,

Vinayaka Mission's Kirupananda Variyar Medical College and

Hospitals, Salem, Tamilnadu.

E-mail:drkannang@yahoo.com

DOI: $10.14260 /$ jemds $/ 2016 / 1729$
The World Health Organisation (WHO) defines diarrhoea wasting syndrome along with a positive HIV serology test to be an AIDS-defining illness. [3]

GIT pathogens are the commonest cause of diarrhoea in HIV/AIDS patients that may lead to mortality and comorbidities in countries like India. In addition to GIT pathogens, many other factors like nutritional deficiencies, autoimmune dysfunction and drugs like ampicillin may lead to diarrhoea in HIV/AIDS patients.

Isospora was first described by Virchow in 1860, but it was named only in 1923. It is coccidian protozoa that can produce isosporiasis which is commonly found in the tropical and subtropical climates. Isosporiasis, also known as cystoisosporiasis occurs worldwide, but predominantly in tropical and subtropical regions. Immunocompromised patients including those who are HIV-infected are at increased risk for chronic, debilitating illness. Although, Isospora belli completes its life cycle in humans, the oocysts shed in the faeces of infected individuals must mature (sporulate) outside the host in the environment to become infective. On the basis of limited data, the maturation process is completed in approximately 1 to 2 days, but might occur more rapidly in some settings. Infection is acquired by the consumption of oocyte, after which the parasite invades intestinal epithelial 
cells. Within a few days oocysts are infective, as sporulation occurs resulting in a mature ellipsoidal oocyst containing two sporocysts each with four sporozoites. ${ }^{44,5]}$ Eight sporozoites released from two sporocysts in the upper small intestine invade the epithelial cells of the distal duodenum and proximal jejunum. Inside the cytoplasm of the enterocyte, the parasite undergoes asexual multiplication to produce trophozoites. Some of the trophozoites undergo sexual cycle and produce oocysts, which are passed in the faeces. Thus, transmission is presumed to be via food and water contaminated with human faeces.

Clinical manifestations include watery, non-bloody diarrhoea, which may be associated with abdominal pain, cramping, anorexia, nausea, vomiting and low-grade fever. The diarrhoea can be profuse and prolonged, particularly in immunocompromised patients, resulting in severe dehydration, electrolyte abnormalities such as hypokalaemia, weight loss and malabsorption. Acalculous cholecystitis/cholangiopathy and reactive arthritis also have been reported.

Typically, infection is diagnosed by detecting Isospora oocysts (Dimensions: 23-36 $\mu \mathrm{m} \times 12-17 \mu \mathrm{m}$ ) in faecal specimens. Oocysts may be shed intermittently and at low levels, even by patients with profuse diarrhoea. Diagnosis can be facilitated by repeated stool examinations with sensitive methods, such as modified acid-fast techniques, on which oocysts stain bright red[6] and UV fluorescence microscopy, under which they autofluoresce. Infection also can be diagnosed by detecting oocysts in duodenal aspirates/mucus or developmental stages of the parasite in intestinal biopsy specimens. Extraintestinal infection such as in the biliary tract, lymph nodes, spleen and liver, has been documented in postmortem examinations of HIV-infected patients.

Diagnosis of Isospora belli is dependent in identification of the parasite oocyst in stool, typically either by examination of wet mounts or by acid fast staining.[6] Unsporulated oocysts of Isospora belli are elliptical, measuring 20-33 um X 10-19 um. Inside each oocyst develop two sporoblasts, which later on convert into sporocysts. Oocysts can be stained with auramine-rhodamine or AFB. With AFB oocysts appear red in colour. Unstained oocysts are autofluorescent, appearing violet under UV light and green under green or blue-violet light. Peripheral blood eosinophilia and stool Charcot-Leyden crystals have been reported with isosporiasis.[7] Trophozoites of Isospora belli have been reported to occur in the mediational and mesenteric lymph nodes, gall bladder, liver and spleen. Histopathological examination of the small bowel in patients with Isospora belli reveals shortened villi, hypertrophic crypts and infiltration of the lamina propria with inflammatory cells, particularly eosinophils. ${ }^{[8]}$ A highly sensitive and specific method of diagnosis has employed PCR with primers for small subunit rRNA sequences of Isospora belli.

The drug of choice is trimethoprim-sulfamethoxazole (TMP-SMX). Because of high relapse/recurrence within 6 to 8 weeks of stopping therapy, lifelong suppressive therapy with a lower dose of TMP-SMX or weekly sulfadoxinepyrimethamine is recommended.[8] Now Roxithromycin and Diclazuril are in use.

\section{MATERIALS AND METHODS}

A cross-sectional study was conducted between June 2015 to May 2016 in the Department of Dermatology, Venereology and Leprology, Vinayaka Mission's Kirupananda Variyar Medical College and Hospitals, Salem, Tamilnadu, which is situated in a rural area. All seropositive patients with diarrhoea were enrolled in the study. The CD4 cells count determination was performed at nearest ART centre.

A total of 250 HIV infected patients were included in this study after obtaining approval from the Institutional Ethical Committee. Out of the 250 HIV infected patients 74 patients had diarrhoea, while the remaining were non-diarrhoeal individuals. HIV infected non-diarrhoeal subjects were included to analyse the prevalence of asymptomatic infection by intestinal parasites. Stool samples were examined by both wet mount and concentration technique in the microbiology lab. Informed consent was obtained from the study suspects.

Parasitic infections were diagnosed by examination of stool specimens as fresh wet mounts and modified acid fast stain. Fresh and concentrated stool specimens were examined as saline wet mounts to detect motile trophozoites and as iodine wet mounts to detect ova, larva and cysts. Air dried smears from fresh stool samples were fixed and stained by a modified acid fast stain to detect the coccidian parasites, Cryptosporidium, Isospora and Cyclospora species.

\section{RESULTS}

A total of 250 subjects were included in the one year study period. Out of 250 patients, 142 (56.8\%) were males and 108 $(43.2 \%)$ were females (Table 1). Most of the patients were in the age group of 31 - 40 years, of which majority were males (Figure 1). Of the patients with diarrhoea, 49 were males and 25 were females (Figure 3). GIT pathogens were found in stool of $74(29.6 \%)$ patients with diarrhoea. Cryptosporidium parvum were seen in most of the patients, i.e. 47 patients, Entamoeba histolytica in 21 patients, Giardia Intestinalis in 4 patients and followed by Isospora belli in 2 patients (Figure 2). The CD4 count of the patients with diarrhoea is as follows, 39 patients (52.7\%) had less than 200 cells/uL, 31 patients (41.8\%) between 200 - 500 cells/uL and 4 patients $(0.05 \%)$ greater than 500 cells/uL (Figure 4 ).

\begin{tabular}{|c|c|c|}
\hline Total No. of Patients & $\mathbf{2 5 0}$ & $\mathbf{\%}$ \\
\hline Male & 142 & $56.8 \%$ \\
\hline Female & 108 & $43.2 \%$ \\
\hline \multicolumn{2}{|c|}{ Table 1. Sex Wise Distribution } \\
\hline
\end{tabular}

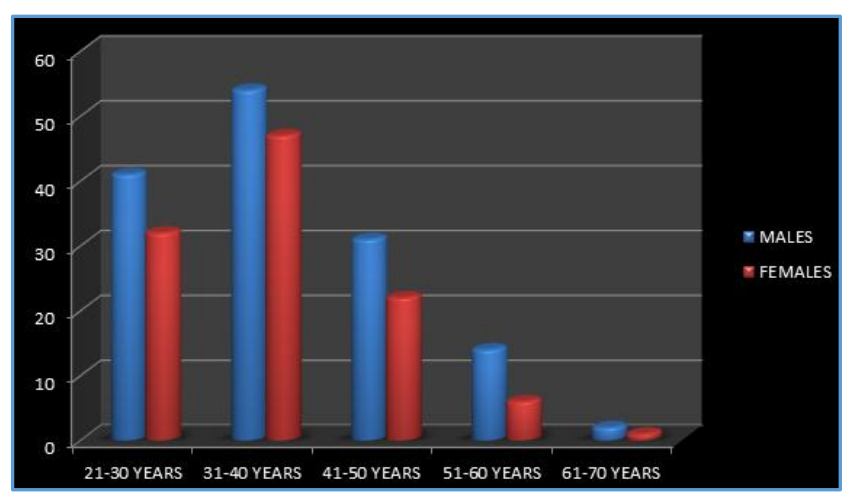

Figure 1. Age and Sex Wise Distribution 


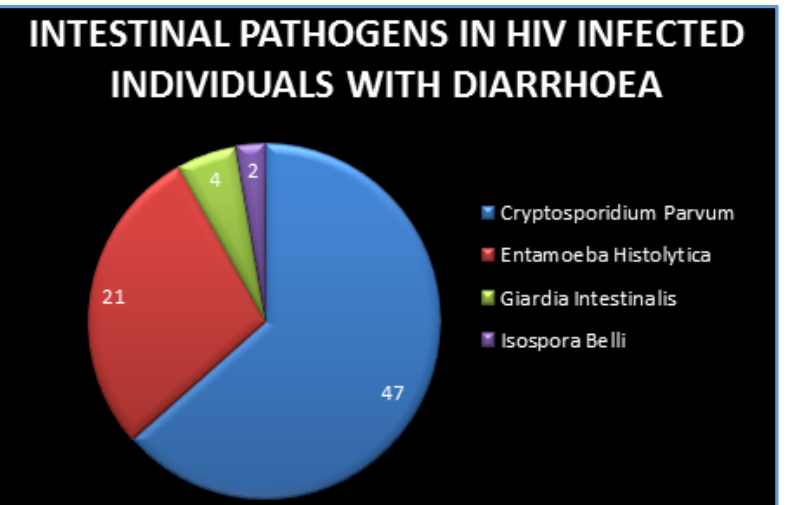

Figure 2. Intestinal Pathogens in HIV Infected Individuals with Diarrhoea

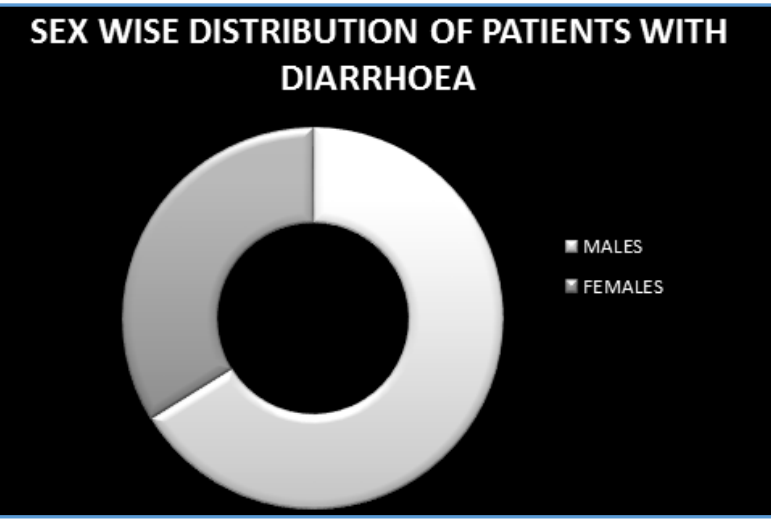

Figure 3. Sex Wise Distribution of Patients with Diarrhoea

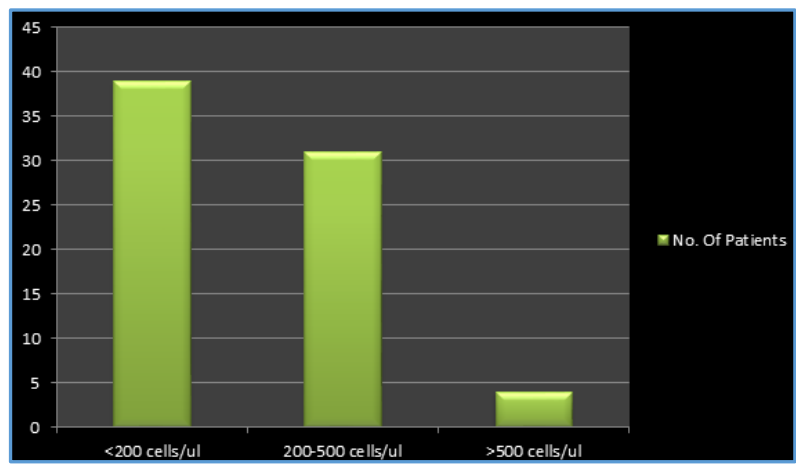

Figure 4. CD4 Count in Patients with Diarrhoea

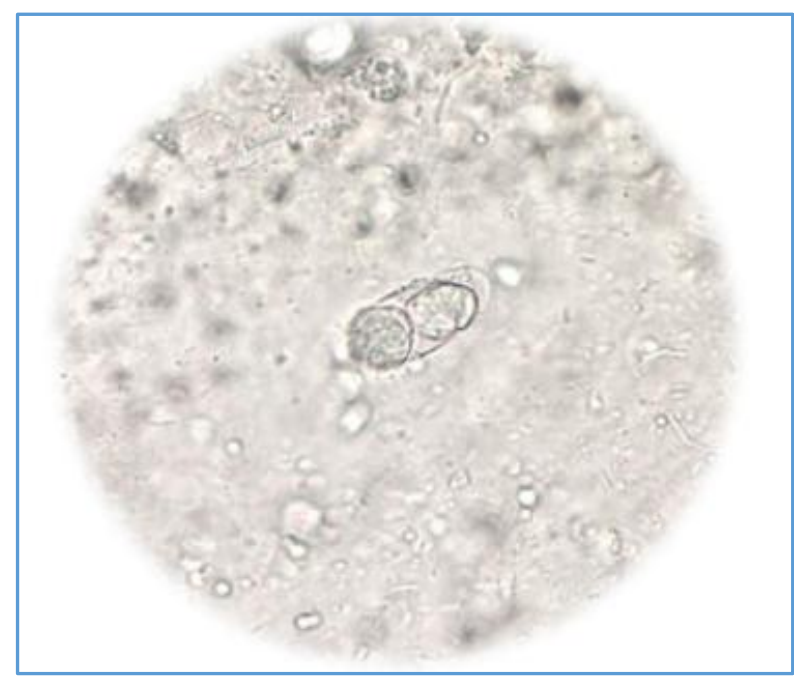

Figure 5. Isospora belli Seen by Wet Mount

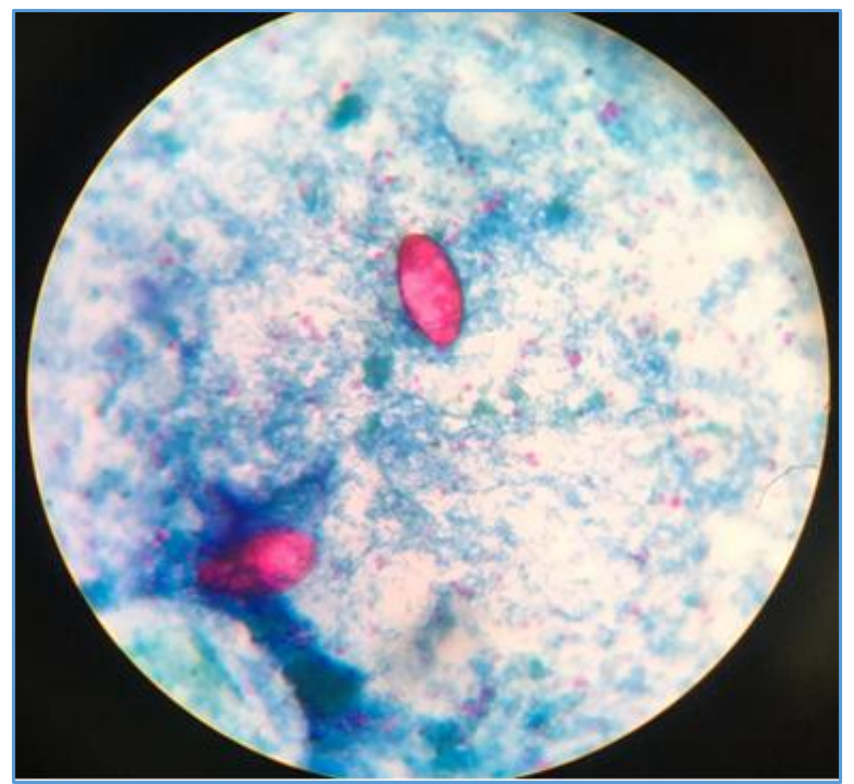

Figure 6. Isospora belli Seen by Modified Acid Fast Stain of Stool

\section{DISCUSSION}

Diarrhoea is one of the most common manifestation of HIV/AIDS. The enteric parasites cause self-limiting diarrhoea of short duration in healthy individuals, but in AIDS patients these causes chronic diarrhoea which may sometimes be lifethreatening. ${ }^{[9]}$ When the CD4 cell count falls in HIV patients due to reduced immunity, the affected patients may develop many major opportunistic infections like pulmonary tuberculosis and Pneumocystis carinii pneumonia.

In this study, the HIV infection was seen more in males than females which is in concordance to studies by Ayyagari et al.[10] It was observed that patients in the age group of 31 - 40 years are mostly affected in our study.

The prevalence of intestinal parasites in HIV/AIDS patients in our study was $29.6 \%$, which is lower than the study by Hailemariam et al.[11] Among patients with diarrhoea, common coccidian parasite found is Cryptosporidium parvum with a prevalence of $63.5 \%$, which is consistent with studies by Mohandas et al[12] and more than studies by Prasad et al and Sintayehu et al.[9,13] Cryptosporidium parvum produces a cholera-like watery or mucous diarrhoea in HIV patients. Diarrhoea relatively is more severe, profuse and watery with as many as 70 stools per day and loss of body fluids even up to 17 litres/day. The prolonged diarrhoea may lead to significant weight loss.[14]

Among non-coccidian parasites, Entamoeba histolytica was the commonest with a prevalence of $28.3 \%$ and is similar to the study by Fontanet et al. Ascaris lumbricoides and nematode $\mathrm{S}$. stercoralis as were observed by Fontanet et al, [15] is not seen in our study.

Isospora belli with a prevalence of $2.7 \%$ is observed in our study, which is lower than what is observed in the study by Gupta et al[16] and other studies. Isospora belli was seen only in HIV infected patients presenting with diarrhoea. The coccidian parasites (Cryptosporidium parvum, Isospora belli, Cyclospora spp. and Microsporidium spp.) are foremost among the intestinal parasites in HIV infected patients.[17] 


\section{CONCLUSION}

The prevalence of Isospora belli in our study was $2.7 \%$. Even though the incidence of Isospora belli in HIV infected diarrhoea patients is very less when compared to the other GIT pathogens, routine stool examinations are to be done for Isospora belli so that it can reduce the morbidity and mortality associated with the GIT pathogens. Water contamination should be investigated to protect the public health, particularly for the rural areas as they are more prone for the risk of transmission of GIT pathogens. The study had some limitations. We could not use the immunofluorescence technique due to the non-availability, otherwise the number of Isospora belli in our study would have been more.

\section{REFERENCES}

1. Smith PD, Lane HC, Gill VJ, et al. Intestinal infections in patients with AIDS: etiology and response to therapy. Ann Intern Med 1988;108(3):328-33.

2. Thomas PD, Forbes A, Green J, et al. Guidelines for the investigation of chronic diarrhoea, 2nd edition. Gut 2003;52(Suppl 5):v1-15.

3. WHO case definitions of HIV for surveillance and revised clinical staging and immunological classification of HIVrelated disease in adults aged 15 years or older. SEARO Publications on HIV/AIDS: 2006. http://www.searo.who.int.

4. Wenyon CM. Observations on the common intestinal protozoa of man: their diagnosis and pathogenicity. Lancet 1915;186(4813):1173-83.

5. Faust EC, Giraldo LE, Caicedo G, et al. Human isosporosis in the western hemisphere. Am J Trop Med Hyg 1961;10(3): 343-9.

6. Ng E, Markell EK, Fleming RL, et al. Demonstration of Isospora belli by acid-fast stain in a patient with acquired immune deficiency syndrome. J Clin Microbiol 1984;20(3):384-6.
7. Trier JS, Moxey PC, Schimmel EM, et al. Chronic intestinal coccidiosis in man: intestinal morphology and response to treatment. Gastroenterology 1974;66(5):923-35.

8. Pape JW, Verdier RI, Johnson WD. Treatment and prophylaxis of Isospora belli infection in patients with the acquired immunodeficiency syndrome. $\mathrm{N}$ Engl $\mathrm{J}$ Med 1989;320(16):1044-7.

9. Prasad KN, Nag VL, Dhole TN, et al. Identification of enteric pathogens in HIV-positive patients with diarrhoea in northern India. J Health Popul Nutr 2000;18(1):23-6.

10. Ayyagari A, Sharma A, Prasad K, et al. Spectrum of opportunistic infections in Human Immunodeficiency Virus (HIV) infected cases in tertiary care hospital. Indian J Med Micobiol 2000;18(3):106-9.

11. Hailemariam G, Kassu A, Abebe G, et al. Intestinal parasitic infections in HIV/AIDS and HIV seronegative individuals in a teaching hospital, Ethiopia. Jpn J Infect Dis 2004;57(2):41-3.

12. Mohandas K, Sehgal R, Sud A, et al. Prevalence of intestinal parasitic pathogens in HIV seropositive individuals in Northern India. Jpn J Infect Dis 2002;55(3):83-4.

13. Fekadu S, Taye K, Teshome W, et al. Prevalence of parasitic infections in HIV-positive patients in southern Ethiopia: a cross-sectional study. J Infec Dev Ctries 2013;7(11):86872.

14. Arora D, Arora B. Medical Parasitology. $2^{\text {nd }}$ edn. New Delhi: CBS Publishers and Distributors 2000.

15. Chavan NS, Chavan SN. Intestinal parasitic infections in HIV infected patients. Int J Curr Microbiol App Sci 2014;3(2):265-70.

16. Gupta S, Narang S, Nunavath V, et al. Chronic diarrhoea in HIV patients: prevalence of coccidian parasites. Indian J Med Micobiol 2008;26(2):172-5.

17. Deorukhkar S, Katiyar R, Saini S, et al. The prevalence of intestinal parasitic infections in HIV infected patients in a rural tertiary care hospital of western Maharashtra (A 5 year study). Journal of Clinical and Diagnostic Research 2011;5(2):210-12. 